\title{
Latviešu un lietuviešu valodas piemēri ārzemju autoru kalku pētījumos
}

\section{Latvian and Lithuanian loan translation examples in the studies of foreign linguists}

\author{
Anita Butāne \\ Latvijas Universitātes Latviešu valodas institūts \\ Akadēmijas laukums 1, Rīga, LV-1050 \\ E-pasts: anita.butane@inbox.lv
}

Rakstā aplūkoti trīs 19. un 20. gadsimtā tapuši ārzemju autoru pētījumi, kas kā atdarinātājvalodas citu starpā rāda arī latviešu un lietuviešu valodu, - vācu valodnieka Hermaņa Paula (Hermann Paul) monogrāfija Prinzipien der Sprachgeschichte (1886), dāṇu valodnieka Kristiana Sandfelda Jensena (Kristian Sandfeld Jensen) raksts Notes sur les calques linguistiques (1912) un angḷu valodnieka Daglasa Polija (Douglas Pauley) disertācija German Loan Translations in Estonian, Finnish and Hungarian (1980).

Raksta mērkis ir atspoguḷot minētajos pētījumos fiksētos baltu valodu piemērus, tādējādi vēršot uzmanību uz kalku izplatību un ārzemju autoru izrādīto interesi par baltu valodu aizguvumiem. Ekscerpētais materiāls rakstā grupēts un aprakstīts atbilstoši kalku pamattipiem.

Piemēru analīze liecina, ka aplūkotajos pētījumos iekḷautie baltu valodu kalki pārstāv visus raksturotos pamattipus, t. i., semantiskos kalkus (piem., latv. gailis un liet. gaidys 'šautenes sastāvdaḷa', sal. ar v. Hahn, a. cock, kr. kurok), derivatīvos kalkus (piem., latv. uzdevums un liet. užduotis 'uzdevums', sal. ar v. Aufgabe), kā arī sintaktiskos un frazeolog̣ismu kalkus (piem., liet. kas per žmogus 'kas par cilvēku', sal. ar v. was für ein Mann), bet visplašākais piemēru klāsts kopumā sniegts derivatīvajiem kalkiem.

Papildus citētajiem baltu valodu kalkiem šajā rakstā minēti arī daži citi piemēri, kuru morfosintaktiskās vai semantiskās struktūras līdzība, autores ieskatā, l̦auj tos pievienot analizētajos kalku pētījumos uzrādītajiem citvalodu atbildumiem (piem., it. dente di latte, sp. diente de leche, v. Milchzahn, kr. moločnyj zub, kā arī latv. piena zobs un liet. pieninis dantis), un vienlaikus akcentēta arī kalkošanas varbūtība, uz ko norādījuši vairāki kalku pētnieki.

Atslēgvārdi: aizguvumi; kalki; citvalodas paraugs; starpkultūru un starpvalodu ietekme. 


\section{Kalku traktējums valodniecībā}

Valodniecībā kopumā, jaungramatisma, sociolog̣isma un deskriptīvisma ideju kontekstā uzsverot divvalodīga vai daudzvalodīga indivīda, kā arī modeḷa/parauga lomu, kalki aprakstīti kā plaši izplatīti aizguvumi, kas ieviesti citās valodās nosauktu jaunu jēdzienu apzīmēšanai un liecina par starpkultūru ietekmi (sk., piem., Bloomfield 1935, 444-460; Haugen 1953, 383-411).

Latviešu valodniecībā kalkošana arī aplūkota kā vispārēja un likumsakarīga parādība (sk., piem., Ahero 1967; Baldunčiks 2014; Butāne 2016), tomēr vairāk izplatīts ir normatīvais skatījums. Tas izteikti pārstāvēts, piem., Intas Freimanes (1993) monogrāfijā Valodas kultūra teorētiskā skatījumā, kur autore, balstoties uz Prāgas strukturālisma atziņām, latviešu valodas kalkus ${ }^{1}$ atbilstoši sava pētījuma mērķim analizējusi nodaḷā par funkcionālajām atkāpēm no latviešu literārās valodas normām, proti, kā tādus nevēlamus valodas līdzekḷus, kuru lietojumā atkāpes radušās citas valodas ietekmē.

\section{Kalku piemēri}

Ir ierasti par latviešu valodas kalkiem lasīt latviešu valodnieku darbos (sk., piem., Gailums 1951; Laua 1969; Freimane 1993), savukārt par lietuviešu valodas kalkiem - lietuviešu valodnieku publikācijās (sk., piem., Pikčilingis 1971; Palionis 1999; Paulauskienè 2004), taču abu minēto baltu valodu aizgūtais materiāls ietverts arī ārzemju autoru pētījumos.

Šajā rakstā atspoguḷoti trīs ārzemju autoru pētīijumos, t. i., Hermaņa Paula (Hermann Paul) monogrāfijā Prinzipien der Sprachgeschichte (1886), Kristiana Sandfelda Jensena (Kristian Sandfeld Jensen) rakstā Notes sur les calques linguistiques (1912) un Daglasa Polija (Douglas Pauley) disertācijā German Loan Translations in Estonian, Finnish and Hungarian (1980), fiksētie latviešu un lietuviešu valodas kalku piemēri, tādējādi vēršot uzmanību uz ārzemju autoru izrādīto interesi par baltu valodu aizguvumiem un vienlaikus popularizējot pasaules valodniecībā paustos uzskatus par kalkošanas vispārējo būtību un kalku izplatību.

\subsection{Hermaņa Paula monogrāfija Prinzipien der Sprachgeschichte}

Monogrāfijas Prinzipien der Sprachgeschichte (1886) autors - vācu valodnieks, jaungramatiķis H. Pauls - nodaḷā Sprachmischung ${ }^{2}$ atzinis, ka,

Terminu „kalks” I. Freimane te attiecinājusi arī uz aizguvumu otro veidu - identiskajiem leksiskajiem aizguvumiem jeb identismiem.

2 H. Paula monogrāfijas pirmizdevums nācis klajā 1880. gadā, bet nodaḷa par valodu „sajaukšanos" ietverta 2. izdevumā (sk. Paul 1886). 
īstenojoties valodu kontaktiem, līdzās ,svešā materiāla” pārņemšanai tiek izmantots arī „svešs paraugs” (Paul 1886, 339, 347-348; par to sk. arī Butāne 2016, 36-37). Abu aizguvumu veidu nošķiršanai konkrēti termini minētajā nodậā nav izmantoti, bet apraksts liecina, ka runa ir par identismiem un kalkiem.

Autora ieskatā, kalki rodas, pēc citvalodas parauga darinot jaunus vārdus un valodā jau esošiem vārdiem aizgūstot jaunu nozīmi - ìpaši tehniskajā un zinātniskajā valodā -, kā arī veidojot frazeolog̣ismus un sintaktiskas konstrukcijas.

Nedaudzo kalku piemēru vidū $\mathrm{H}$. Pauls $(1886,348)$ minējis pēc vācu was für ein Mann (tiešā tulkojumā: „kas par cilvēku”) parauga veidotu sintaktisko konstrukciju lietuviešu valodā. Attiecīgo kalkoto konstrukciju H. Pauls gan nav uzrādījis, bet tā līdzās citu valodu atbildumiem (v. was für ein Mann, kr. čto za čelovek) vēlāk fiksēta kāda cita autora darbā, kas arī aplūkots šajā rakstā, proti, K. Sandfelda Jensena publikācijā Notes sur les calques linguistiques (1912, 172):

(1) liet. kas per žmogus.

\subsection{Kristiana Sandfelda Jensena raksts Notes sur les calques linguistiques}

Dāṇu valodnieks K. Sandfelds Jensens, kā atzīts, pārņēmis jaungramatisma uzskatus un interesējies par valodu līdzīgajām iezīmēm (par to sk. Gáldi 1942), kas var rasties gan neatkarīgi, gan savstarpējā ietekmē.

1912. gadā publicētais K. Sandfelda Jensena raksts Notes sur les calques linguistiques aizguvumu pētniecībā nozīmīgs ar to, ka tajā, visticamāk, rodams pirmais mēg̊inājums veidot kalku klasifikāciju (par to sk. Veltheyme Velten 1930, 335), savukārt ieklautie latviešu un lietuviešu valodas piemēri l̦auj to atzìt par nozīmīgu arī baltu valodniecībā.

Rakstā autors nošķīis trīs kalku pamattipus:

1) semantiskie kalki (vārdi, kam pēc citvalodas parauga paplašināta semantika);

2) derivatīvie kalki (pēc citvalodas parauga darināti atvasinājumi un salikteņi);

3) sintaktiskie kalki (pēc citvalodas parauga veidotas sintaktiskas konstrukcijas - frāzes un izteicieni).

Latviešu un lietuviešu valodas piemēri atrodami visu minēto pamattipu aprakstā.

Semantisko kalku piemēru klāstā minēti šādi latviešu un lietuviešu valodas vārdi ar aizgūtu nozīmi:

(2) latv. gailis un liet. gaidys, kam līdzās nozīmei 'vistu tēviņš’ pēc citvalodas parauga ieviesta nozīme 'šautenes sastāvdalạa' (sal. ar v. Hahn, a. cock, d. hane, kr. kurok, bulg. petelka u. c.); 
(3) liet. miežis, kam līdzās nozīmēm 'labības augs; grauds' pēc citvalodas parauga ieviesta nozīme 'acs iekaisums' (sal. ar v. Gerstenkorn, d. bygkorn, it. orzujuolo u. c.) (Sandfeld Jensen 1912, 168).

Derivatīvo kalku aprakstā ietverti divu jēdzienu - 'sveicināt' un 'labdarība' apzīmējumi latviešu un/vai lietuviešu valodā:

(4) latv. labdarīšana un liet. geradejystè (sal. ar lat. beneficium, v. Wohltat, kr. blagodejanie, p. dobrodziejstwo u. c.) (Sandfeld Jensen 1912, 170);

(5) liet. sveikinti (sal. ar lat. salutare, senaugšv. heilazzen, sl. čelovati u. c.) (Sandfeld Jensen 1912, 169).

Sintaktiskajiem kalkiem veltītajā izklāstā fiksēta iepriekš (1) piemērā minētā konstrukcija lietuviešu valodā, proti, kas per žmogus, kam par paraugu bijusi konstrukcija vācu valodā - was für ein Mann (Sandfeld Jensen 1912, 172).

Tātad kopumā K. Sandfelds Jensens uzrādīịis septinuus baltu valodu piemērus, no kuriem divi ir latviešu valodas kalki (sk. ekscerptus (2) un (4) piemērā) un pieci - lietuviešu valodas kalki (sk. ekscerptus (1), (2), (3), (4) un (5) piemērā), bet abas valodas kā atdarinātājvalodas varētu minēt arī vairākos citos autora aplūkotajos gadījumos. Tā, piem., līdzīgi kā daudzās citās valodās, arī latviešu un lietuviešu valodā vārdam, kas izsaka nozīmi 'mutes dobuma orgāns', ir arī nozīme 'valoda(-as)': sal. lat. lingua, fr. langue, v. Zunge, d. tunge, a. tongue, kr. jazyk, som. kieli u. c. (Sandfeld Jensen 1912, 168) un latv. mēle un liet. liežuvis ${ }^{3}$.

Līdzās šādiem semantiskajiem kalkiem var minēt arī K. Sandfelda Jensena fiksētos derivatīvos kalkus, kam atbildumi senāk vai mūsdienās atrodami gan latviešu, gan lietuviešu valodā. Piem., v. genugtun un kr. udovletvorit', kas, kā atzīts, darināti pēc latīṇu satisfacere parauga (Sandfeld Jensen 1912, 171), varētu pievienot latv. gandarīt un senāk lietoto liet. gandaryti ${ }^{4}$.

Kārlis Mīlenbahs $(1901,1)$ par attiecīgajiem baltu valodu darinājumiem savulaik rakstīiis šādi: „Vācu Genugtuung vārdu pa vārdam pārceldami, kḷ̂ūstam pie rakstu valodā sastopamā vārda gandarǐšana, gandarība, gandarījums. Šis vārds nav jaunākā laikā cēlies, bet sastopams jau mūsu senākajos rakstos, pazīstams arī leišu rakstu valodai gandaryti. To ievērojot, dažs labs varētu

3 Ja vien nav norādīts cits avots, šì raksta autores pievienotie latviešu valodas atbildumi fiksēti saskaņā ar Latviešu literārās valodas vārdnīcu (elektroniskā versija pieejama vietnē www.tezaurs. lv/llvv/) un lietuviešu valodas atbildumi - saskaņā ar izdevumu Lietuvių kalbos žodynas (elektroniskā versija pieejama vietnē www.lkz.lt).

4 Vārdu gandaryti minējis arī Augusts Šleihers (August Schleicher) darbā Handbuch der Litauischen Sprache (1856, 141), norādot, ka šāda veida darinājumus fiksējis [Gotfrīds] Ostermeiers ([Gottfried] Ostermeyer), bet viņš savukārt tādus neesot nedz dzirdējis, nedz lasīiis. 
iedomāties, ka gandarīt īsts latviešu vārds, kas cēlies jau leišu un latviešu kopdzìves laikā; bet tas tā nebūt nav. Gandarìt tāpat kā leišu gandaryti ir svešinieki, darināti pēc vācu genugtun, šis atkal pēc latīṇu satisfacere."

Arī vairākiem citiem K. Sandfelda Jensena pētìjumā minētajiem kalkiem var pievienot abu baltu valodu piemērus. Tā, piem., it. dente di latte, sp. diente de leche, v. Milchzahn un kr. moločnyj zub (Sandfeld Jensen 1912, 172), ar ko tiek nosaukti pirmie zobi, kas, bērnam augot, izkrīt, tāpat ir tieši atbildumi gan latviešu, gan lietuviešu valodā: sal. latv. piena zobs un liet. pieninis dantis.

\subsection{Daglasa Polija disertācija German Loan Translations in Estonian, Finnish and Hungarian}

ASV pētnieks D. Polijs Indiānas Universitātē aizstāvētajā disertācijā German Loan Translations in Estonian, Finnish and Hungarian (1980) arī īsi aprakstīijis kalku pamattipus (derivatīvos, semantiskos un sintaktiskos kalkus), bet sīkāk analizējis atvasinājumus un salikteņus, kas igauņu, somu un ungāru valodā darināti pēc vācu valodas parauga. Pētījuma beigu dạ̦ā ietverta vārdnīca ar šķirkḷiem, kuros uzrādīts gan vācu valodas paraugs, gan kalkotie igauņu, somu un ungāru valodas vārdi, gan nereti arī citu valodu atbildumi.

Nozīmīgi, ka atšķirībā no daudziem citiem kalku aprakstiem te attiecīgie atvasinājumi un salikteņi dalīti morfēmās un komponentos, tādējādi atvieglojot sastatīto morfosintaktisko struktūru salīdzināšanu. Piem., parādīts, ka, nosaucot nierēs izveidojušos nogulsnējumu, vairākās valodās izmantotas leksēmas niere un akmens: v. Nierenstein $(<$ Niere + Stein $)$, ig. neerukivi $(<$ neer + kivi), som. munuaiskivi (< munuainen + kivi $)$, ung. vesekö $(<$ vese + kó $)$, zv. njursten (< njure + sten) u. c. (Pauley 1980, 113). Latviešu un lietuviešu valodā izmantotie sinonīmiskie identismi - latv. nefrolìts un liet. nefrolitas - rāda arī atbilstīgās grieķu valodas leksēmas (gr. nephros 'niere' un lithos 'akmens'), bet D. Polija piedāvātajam šķirklim, kurā minēti vairāki attiecīgā jēdziena kalkotie apzīmējumi, varētu pievienot arī latv. nierakmens un liet. inkstu akmuo (inkstas 'niere' + akmuo 'akmens').

Salīdzinājumā ar iepriekš aplūkoto K. Sandfelda Jensena rakstu D. Polija pètījums ir daudz plašāks, un arī abu baltu valodu piemēru kopā te ir krietni vairāk.

Tālāk, darinājumus grupējot pēc sastāva un vārdšķiras, alfabētiskā secībā uzskaitīti D. Polija fiksētie latviešu valodas kalki, kas šā raksta vajadzībām ekscerpēti no dažādiem šķirkḷiem (attiecīgais paraugs un citvalodu atbildumi ar dalījumu morfēmās/komponentos apjoma ierobežošanas nolūkā te nav citēti):

\footnotetext{
Sk. Butkus 2003.
} 
1) atvasinājumi:

(6) aizspriedums (159) ${ }^{6}$, iegriezums (108), iepircējs (166), ieskats (110), izdevējs (165), izsitums (169), nesmēkēetājs (134), pārskats (192), pēcraksts ${ }^{7}$ (157), piegriezējs (193), piesēdētājs (43), pretinde (42), pretruna (72), pretuzbrukums (74), uzdevums (194), uzpircējs (99);

2) salikteņi:

a) lietvārdu salikteņi:

(7) aculiecinieks (93), ābolskābe (123), ātrskrējējs (186), ātrvilciens (92), biezādis (140), brīnumdarītājs (129), caurmērs ${ }^{8}$ (82), celmlauzis (152), cilvēkēdājs (57), dail,runis (185), daudzzinis (156), debesskrāpis (181), dienasgrāmata (81), divkauja (85), divskanis (83), dzeloṇcūka (157), dzelzceḷ š (168), gadsimts (61), galvaspilsēta (58), grāmatsējējs (49), kabatzaglis (151), krūšturis (51), labdaris (47), laikraksts (121), ledlauzis (108), leduslācis (155), lidmašīna (36), lielpilsēta (126), lietussargs (203), likumdevējs (118), lìdzskanis (72), laundaris (122), padomdevējs (34), pašslepkavība (190), patskanis (210), pienskābe (115), priekšāda (98), priekšdziedātājs (63), priekšgājējs (98), priekšjājējss (140), priekšlasītājs (117), priekšpilsēta (189), priekšsēdètājs (160), priekšspēle (159-160), priekšstrādnieks (97), priekštecis (98), priekštelpa (41), priekštiesība (161), pussala (11, 146), rakstāmgalds (80), rakstāmmašinna (202), sālskābe (105), sīktirgotājs (172), skudrskābe (100), tālrunis (197), üdenskritums (211), vairogdziedzeris (198), vēderrunātājs (207), viḷnlauzis (53), zilskābe (106), zobārsts (79), zvērudārzs (215);

b) īpašības vārdu salikteņi:

(8) labvēlīgs (48), pareizticīgs (137-138), patstāvīgs (109), šaursirdīgs (131), valısirdīgs (136), vieglprātīgs (119), vienbalsīgs (204), vienlaicìgs (180);

3) vārdkopas:

(9) darba devējs (87), divpadsmitpirkstu zarna (85).

Kā liecina uzskaitījums, kopumā autors devis 88 latviešu valodas piemērus. Atvasinājumu un salikteņu vidū iezīmējas noteiktas vārdu apakšgrupas

${ }^{6}$ Iekavās te un tālāk uzskaitīijumā norādīts disertācijas lappuses numurs, kur konkrētais piemērs minēts.

7 Darinājumi ar pêc- un pret- šajā rakstā aplūkoti pie atvasinājumiem atbilstoši Latviešu valodas gramatikai (Vulāne 2013, 212-214).

8 Darinājumi ar caur- un priekš-, kas latviešu valodniecībā tiek dēvēti par prefiksoīdiem (Vulāne 2013, 212), šajā rakstā aplūkoti pie salikteņiem. 
ar konkrētiem vārddarināšanas līdzekḷiem, piem., atvasināti lietvārdi, kuru pamatā ir priedēkḷverbi ar prefiksiem ie-, pie-, uz- (iegriezums, piesēèetājs, uzpircējs u. c.); lietvārdu salikteņi ar derivatīvo galotni -is (labdaris, tālrunis, patskanis u. c.); lietvārdu salikteni ar otro komponentu -skābe (ābolskābe, pienskābe, sālskābe, skudrskābe, zilskābe); lietvārdu salikteņi ar priekš- pirmajā komponentā (priekšdziedātājs, priekšpilsēta, priekštiesība u. c.).

Lietuviešu valodas piemērs D. Polija darbā ir tikai viens:

(10) užduotis (194).

Citos šķirkḷ̆os gan ir fiksēti arī vēl citi lietuviešu valodas piemēri, tomēr tie minēti atškịirīgas morfosintaktiskās struktūras uzrādīšanas nolūkā, proti, ne kā kalki, kas līdzinās citvalodu darinājumiem, kam pirmparaugs saskatīts vācu valodā.

Piem., analizējot tādus nedēlas dienas apzīmējumus kā v. Mittwoch (< Mitte 'vidus' + Woche 'nedēḷa'), som. keskiviikko (< keski 'vidus' + viiko 'nedēlala') un ig. kesknädal (< kesk- 'vidus' + nädal 'nedēlà'), secināts, ka attiecīgie lietuviešu un latviešu valodas darinājumi - liet. trečiadienis un latv. trešdiena (Pauley 1980, 212) - atšksiras. Proti, tiem izmantots kārtas skaitḷa vārds ar nozīmi 'trešais' un leksēma diena atšksirībā no vācu un vairākām citām valodām, kurās attiecīgā jēdziena apzīmēšanai izmantoti salikteņi no leksēmām vidus un nedēḷa, kas liecina par atšksirīgo tradīciju svētdienu uzlūkot par nedēḷas pirmo dienu un trešdienu tādējā̀di atzīt par kalendāāās nedēlas vidu.

\section{Problēmjautājumi un secinājumi}

Abos rakstā aplūkotajos 20. gadsimta kalku pētījumos - K. Sandfelda Jensena rakstā Notes sur les calques linguistiques $(1912,172)$ un D. Polija disertācijā German Loan Translations in Estonian, Finnish and Hungarian (1980, 10-11) - uzmanība pievērsta varbūtējai kalkošanai: autori uzsvēruši, ka bieži vien ir neiespējami neapstrīdami pierādīt kalkošanas faktu un/vai kalka parauga valodu.

D. Polijs (1980, 57-58) norādīijis, ka, piem., jēdziena 'valsts galvenā pilsēta' apzīmējumu gadījumā igauṇu, somu un ungāru valodas vārdiem par paraugu varējis būt gan vācu, gan arī kādas citas Eiropas valodas saliktenis, kas darināts, izmantojot leksēmas galva un pilsēta (sal.: v. Hauptstadt $(<$ Haupt + Stadt), ig. pealinn $(<$ pea + linn $)$, som. pääkaupunki $(<$ pää + kaupunki $)$, ung. föváros ( $<$ fö + város), zv. huvudstad (< huvud + stad), norv. hovedstad $(<$ hoved + stad $)$, turk. bassehir $(<$ bas ' + sehir $)$, latv. galvaspilsēta9 $(<$ galva + pilsēta) u. c.).

\footnotetext{
9 Sk. iepriekš ekscerptu (7) piemērā.
} 
Kalkošanas varbūtība akcentēta arī citos kalku aprakstos. Tā, piem., attiecībā uz (5) piemērā K. Sandfelda Jensena minētajiem darinājumiem franču strukturālists Emīls Benvenists (Émile Benveniste 1971, 239, 243) norādījis, ka senaugšvācu heilazzen, iespējams, ir darināts, par paraugu izmantojot latīṇu salutare (verbs, kam pamatā vēlējums salus!), savukārt senslāvu celovati (< celŭ, sal. ar kr. celyj 'vesels, sveiks'), visticamāk, ir kalks, kam paraugs meklējams latīṇu valodā.

Ar varbūtîbu un pieņēmumiem, protams, jārēḳinās arī šajā rakstā citēto latviešu un lietuviešu valodas kalku piemēru gadījumā, jo tie, visticamāk, fiksēti, balstoties tikai uz konstatēto strukturālo līdzību vārdu, vārdkopu un frāžu starpā, t. i., bez konkrētiem faktiem, kas apliecina, kad un kādā valodu kontaktsituācijā attiecīgā valodas vienība radusies.

Visu trīs rakstā aplūkoto pētījumu apskats ḷauj secināt, ka 19. gadsimta beigās, skaidrojot kalku būtību, kā viens no nedaudzajiem piemēriem minēts arī sintaktiskais kalks lietuviešu valodā, savukārt 20. gadsimtā, kalku pētniecībai kḷūstot intensīvākai, līdzās lietuviešu valodas piemēriem daudzu citu valodu vidū ārzemju pētījumos minēti arī latviešu valodas kalki, kas apliecina baltu valodu dotumu nozīmi lingvistiskajā kopainā.

\section{Avoti}

1. Bendiks, Hermanis et al. 1975, 1984, 1987. Latviešu literārās valodas vārdnīca. 8 sējumos. 3., 5., $6_{2}$. Rīga: Zinātne. Pieejams: www.tezaurs.lv/llvv/.

2. Butkus, Alvydas 2003. Latviu-lietuviu kalbu žodynas: apie 43000 žodžių/ Latviešulietuviešu vārdnīca: ap 43000 vārdu. Kaunas: Aesti.

3. Paul, Hermann. 1886. Principien der Sprachgeschichte. 2. Halle: Max Niemeyer.

4. Pauley, Douglas. 1980. German Loan Translations in Estonian, Finnish and Hungarian. Diss. United States, Indiana University.

5. Sandfeld Jensen, Kristian. 1912. Notes sur les calques linguistiques. Festschrift Wilhelm Thomsen zur Vollendung des 70. Lebensjahres am 25. Januar 1912. Leipzig: Otto Harrassowitz, 166-173.

6. Ulvydas, Kazys, Kruopas, Jonas et al. 1956, 1966, 1973. Lietuvių kalbos žodynas. 3., 7., 9. tomas. Vilnius: Valstybinè politinès ir mokslinès literatūros leidykla/ Mintis. Pieejams: www.lkz.lt.

\section{Literatūra}

1. Ahero, Antonija. 1967. Par citu valodu ietekmi vārdu darināšanā. Latviešu valodas kultūras jautājumi. 3. Rīga: Liesma, 12-20.

2. Baldunčiks, Juris. 2014. Kalki un puskalki latviešu valodā: interpretācijas un inventarizācijas jautājums. RES LATVIENSES III. ALİSE LAUA (1914-1994). IN HONOREM. LU Humanitāro zinātņu fakultātes Latvistikas un baltistikas nodaḷas raksti. Kalnača, Andra, Lokmane, Ilze, Urbanoviča, Inta (sast., red.). Rīga: LU Akadēmiskais apgāds, 26-52. 
3. Benveniste, Émile. 1971. Problems in General Linguistics. USA: University of Miami Press.

4. Bloomfield, Leonard. 1935. Language. London: George Allen \& Unwin LTD.

5. Butāne, Anita. 2016. Terminrade un kalkošana. Terminrade Latvijā senāk un tagad. Rīga: Zinātne, 36-42.

6. Freimane, Inta. 1993. Valodas kultūra teorētiskā skatījumā. Rīga: Zvaigzne.

7. Gailums, Klementijs. 1951. Leksika. Padomju Latvijas Skola. 4, 89-99.

8. Gáldi, Ladislaus. 1942. Kristian Sandfeld. Archivum Europae Centro-Orientalis. 8. Heft 1-2, 526-530.

9. Haugen, Einar. 1953. The Norwegian Language in America. 2. Philadelphia: University of Pennsylvania Press.

10. Laua, Alīse. 1969. Latviešu leksikologíija. Rīga: Zvaigzne.

11. Mīlenbahs, Kārlis. 1901. Jaunvārdi. Vārds. 50, 1. [Raksta sākumu un turpinājumu sk. Vārds. 45, 1; Nr. 56, 1; Nr. 57, 1; visu rakstu vienkopus sk. Mīlenbahs, Kārlis. 1909. Jaunvārdi. Daži jautājumi par latviešu valodu. IV. Rīga: RLB, 39-54; pārpublicējums: Mīlenbahs, Kārlis. 2009. Jaunvārdi. Darbu izlase divos sējumos. 1. Rīga: LU Latviešu valodas institūts, 363-374.]

12. Palionis, Jonas. 1999. Kalbos mokslo pradmenys. Vilnius: Jandrija.

13. Paulauskienè, Aldona. 2004. Lietuvių kalbos kultūra. Kaunas: Technologija.

14. Pikčilingis, Juozas. Lietuviu kalbos stilistika. I. Vilnius: Mintis.

15. Schleicher, August. 1856. Handbuch der Litauischen Sprache. I. Grammatik. Prag: J. G. Calve'sche Verlagsbuchhandlung.

16. Vulāne, Anna. 2013. Lietvārda derivatīvais raksturojums. Latviešu valodas gramatika. Nītiņa, Daina, Grigorjevs, Juris (red.). Rīga: LU Latviešu valodas institūts, 212-262.

17. Veltheyme Velten, Harry de. 1930. Studies in the Gothic Vocabulary with Especial Reference to Greek and Latin Models and Analogues. The Journal of English and Germanic Philology. XXIX (3), 332-351.

\section{Summary}

In order to highlight foreign linguists' interest of borrowings in the Baltic languages, as well as some linguistic theories on loan translation, this article discusses three studies published in German, French and English during the 19-20th century - namely, the monograph Prinzipien der Sprachgeschichte (1886) by German linguist Hermann Paul, the article Notes sur les calques linguistiques (1912) by Danish linguist Kristian Sandfeld Jensen, and the doctoral thesis German Loan Translations in Estonian, Finnish and Hungarian (1980) by English linguist Douglas Pauley. These authors have also included Latvian and Lithuanian loan translation examples in their research.

The Latvian and Lithuanian examples quoted in these sources represent all the main types of loan translations or calques described by these authors. Among them are: semantic calques or loan meanings (e.g. Latv. gailis and Lith. gaidys 'detail of a gun', cf. Germ. Hahn, Eng. cock, Rus. kurok); loan creations (e.g. Latv. uzdevums and Lith. užduotis 'task', cf. Germ. Aufgabe), and phraseological and syntactic calques 
(e.g. Lith. kas per žmogus 'what kind of person', cf. Germ. was für ein Mann). The largest amount of examples illustrates loan creations.

Besides, this article includes some other Latvian and Lithuanian examples where the similarities of morphosyntactic and semantic structures allow to speak about calques (e.g. Ital. dente di latte, Span. diente de leche, Germ. Milchzahn, Rus. moločnyj zub, as well as Latv. piena zobs and Lith. pieninis dantis). 